\title{
Coculture of Bovine Demiembryos Prior to Freezing
}

\author{
By M.Schmidt, S.D.Smith, B.Avery, B.Purwantara and T.Greve
}

Department of Clinical Studies, Reproduction, Royal Veterinary and Agricultural University, Frederiksberg, Denmark.

\begin{abstract}
Schmidt,M., S.D.Smith, B.Avery, B.Purwantara and T.Greve: Coculture of bovine demiembryos prior to freezing. Acta vet. scand. 1992, 33, 237-243. - Pregnancy rates after transfer of frozen/thawed bisected embryos, demiembryos, have until now been very low. In the present study it was attempted to improve the freezability rate of demiembryos by culturing them on a monolayer of bovine oviduct epithelial cells (BOEC) prior to freezing. The cultured frozen/thawed demiembryos showed a lower developmental rate than intact embryos. The pregnancy rate $(23 \%)$ following transfer was not different from the pregnancy rate after transfer of unfrozen demiembryos $(26 \%)$. The calving rate (4\%), however, was significantly lower than the calving rate after transfer of fresh demiembryos $(23 \%)$. Although the overall pregnancy rate achieved in this study was low, it can be concluded that a co-culture period upon BOEC prior to freezing does not improve the viability of frozen demiembryos.
\end{abstract}

frozen half embryos; culture; BOEC; pregnancy rate; calving rate.

\section{Introduction}

Bisection of bovine embryos has been used widely to produce identical, monozygotic twins (Willadsen 1981, Schwidersky et al. 1990, Holm et al. 1991). Transfer of these demiembryos yields lower pregnancy rate than transfer of whole embryos possibly due to the reduction in cell numbers. (Willadsen 1981, Lehn-Jensen \& Willadsen 1983, McEvoy \& Sreenan 1990, Schwidersky et al. 1990). Certain experiments, sexing of embryos for example (Schröder et al. 1990), may require intervention on one half of an embryo, while the corresponding other half is preserved by freezing. The freezing process, however, makes another reduction of the number of viable cells, leading to reduced or poor pregnancy results, as shown in several studies in cattle (Lehn-Jensen \& Willadsen 1983, Picard et al. 1985, Picard et al. 1988, Seike et al. 1991), and recently also in sheep (Shelton 1992).

A holding period of $1 / 2-1 \mathrm{~h}$ following bisection is sufficient to allow repair of the actual dam- age inflicted by microsurgery (Albihn et al. 1990 ), whereas a longer culture period could give the demiembryos possibility to increase the number of cells, thus enabling a better survival (L. Picard, pers.comm.).

The aim of the present study was therefore to examine whether culture of demiembryos (DE) on bovine oviduct epithelial cells (BOEC) for a limited period of time prior to freezing would improve their viability following thawing.

\section{Materials and Methods}

Superovulation and embryo collection

Ten days after estrus 195 dairy cows and heifers were treated with $35 \mathrm{mg}$ FSH (Folltropin Vet $^{R}$, Coopers Animal Health Ltd) in a decreasing dosage regimen for 4 days. Seventytwo $\mathrm{h}$ after the initial FSH treatment a single injection of prostaglandin (Estrumat ${ }^{\circledR}$ vet, Coopers Animal Health Ltd) was given to cause luteal regression. Artificial insemination were performed 12 and $24 \mathrm{~h}$ after the on- 
set of standing heat. After 6 days $158(81 \%)$ of the animals were flushed nonsurgically using Dulbeccos PBS containing $36 \mathrm{mg} / \mathrm{l}$ pyruvate, $1000 \mathrm{mg} / \mathrm{l}$ glucose, $25 \mathrm{mg} / \mathrm{l} \mathrm{kanamycinesul-}$ phate and $0.5 \%$ heat inactivated fetal calf serum (FCS). A total of 1030 eggs were recovered of which 626 were considered to be transferable embryos (TE) $(61 \%$ or $4 \mathrm{TE} /$ flushed donor). The intact embryos were washed and stored in the PBS with $10 \%$ FCS until morphological evaluation and onset of transfer, bisection, cultivation or freezing.

\section{Bisection of embryos}

A part of the TE (250), predominantly compacted morulas (CM) and only a few young blastcysts (YB), were bisected as described in Smith et al. (1991) within a droplet of PBS containing $20 \%$ FCS using a compound microscope with 2 Leitz micromanipulators. While being fixed with a holding pipette, embryos were bisected symmetrically with a microsurgical eye blade (Beaver,USA). The bisection was done inside or outside the zona, and with a transfer pipette one half of the embryo was returned to the original zona, and the other half to a surrogate zona from the same donor or from another donor flushed at the same day. The bisection gave rise to a total of 418 demiembryos.

\section{Embryo transfer}

Synchronisation of recipients was done by 2 injections of prostaglandin (Estrumate ${ }^{\circledR}$ vet, Coopers Animal Health Ltd) 11 days apart.

The embryos, intended for transfer (143 intact embryos and 141 demiembryos) originated from valuable donors. They were loaded into $0.25 \mathrm{ml}$ straws and transferred non-surgically to the middle part of the uterine horn ipsilateral to the ovary containing the corpus luteum into recipients that were within $24 \mathrm{~h}$ of cycle synchronisation and of the same breed as the donor cows.

\section{Culture of demiembryos before freezing}

Bovine oviduct epithelial cells (BOEC) were prepared from slaughterhouse oviducts, prepared as previously described (Schmidt et al. 1990).

A part of the demiembryos (243) and 95 intact embryos were cultured for $24 \mathrm{~h}$ on a confluent monolayer of BOEC in TCM-199 with Earles salts supplemented with $10 \%$ FCS, 2 mM glutamine, penicilline 200 i.u. $/ \mathrm{ml}$, streptomycin $200 \mu \mathrm{g} / \mathrm{ml}$, fungizone $2.5 \mu \mathrm{g} / \mathrm{ml}$ in $5 \% \mathrm{CO}_{2}$ in humified air at $38.5^{\circ} \mathrm{C}$. The developmental capacity of the embryos was evaluated based on morphology as follows: compacted morula (CM), young blastocyst (YB), blastocyst (BL), expanded blastocyst (XB), hatching blastocysts (HB) and hatched blastocyst (HA). The viability was assessed as the number of progressive morphological stages each embryo had gone through after a $24 \mathrm{~h}$ culture period. One person made all the evaluations of the developmental stage.

\section{Freezing/thawing of demiembryos}

After the culture period 137 of the demiembryos and 25 of the intact embryos were frozen.

The freezing medium consisted of $10 \%$ sterile glycerol in Dulbeccos PBS supplemented with $10 \%$ FCS. The embryos were equilibrated in the freezing medium for $20-30 \mathrm{~min}$ at room temperature $\left(21^{\circ} \mathrm{C}\right)$, aspirated in $0.25 \mathrm{ml}$ straws each containing 1 embryo and placed at $-6^{\circ} \mathrm{C}$ for $10 \mathrm{~min}$ in the chamber of an automatic alcohol embryo freezer (Julabo HC, FP 50). After seeding, the straws were cooled to $-35^{\circ} \mathrm{C}$ at a cooling rate of $-0.4^{\circ} \mathrm{C} / \mathrm{min}$ after 
Table 1. The number of embryos in each group.

\begin{tabular}{ccccccc}
\hline $\begin{array}{c}\text { TE from } \\
158 \\
\text { flushings }\end{array}$ & $\begin{array}{c}\text { Type of } \\
\text { embryos }\end{array}$ & $\begin{array}{c}\text { Not used } \\
\text { in this } \\
\text { study }\end{array}$ & $\begin{array}{c}\text { Trans- } \\
\text { ferred } \\
\text { fresh }\end{array}$ & $\begin{array}{c}\text { Cul- } \\
\text { tured } \\
\text { in BOEC }\end{array}$ & $\begin{array}{c}\text { Frozen } \\
\text { after } \\
\text { culture }\end{array}$ & Thawed \\
\hline 626 & $418 \mathrm{DE}$ & 34 & 141 & 243 & 137 & 137 \\
& $376 \mathrm{IE}$ & 138 & 143 & 95 & 25 & 16 \\
\hline
\end{tabular}

$\mathrm{TE}=$ Transferable embryos.

BOEC $=$ Bovine oviduct epithelial cells.

which they were plunged into liquid nitrogen at $-196^{\circ} \mathrm{C}$.

Thawing was done 1-24 months later in air for $1 \mathrm{~min}$ at room temperature. The embryos were then placed in 1.0 M sucrose for 6-8 min and subsequently transferred to PBS with $10 \%$ FCS and evaluated for stage of development and embryo quality grade.

The number of embryos entering each group is seen in Table 1.

Some embryos were lost under the processes and some of the embryos, which were frozen instantly, were used in other studies.

\section{Evaluation of the treatments \\ of the demiembryos}

The success of the culture/freezing/thawing procedures was measured by judging the viability of the demiembryos by 2 methods: transfer of the demiembryos to synchronized heifers, while 141 fresh demiembryos made the control group, or reculture of the demiembryos for $24 \mathrm{~h}$ in order to measure the developmental rate. They were cultured for $24 \mathrm{~h}$ in a Nunclon 96-microwell plate as described before, but the bovine oviduct cells were in 1:100 $\mathrm{vol} / \mathrm{vol}$ suspension prepared 1 day prior to use (Schmidt et al. 1991) instead of a monolayer. As a minor control group 14 cultured/frozen/thawed intact embryos followed the same procedure.

\section{Statistical analysis}

The data were analyzed statistically using the Chi-square test (SAS Institute, 1988). The level of significance was $p \leq 0.05$.

\section{Results \\ Culture prior to freezing}

The viability following culture on BOEC monolayer was assessed by the capacity of the embryo to enter through a number of the developmental stages e.g. from $\mathrm{CM}$ to $\mathrm{YB}$, from YB to BL, etc (Table 2). The number of degenerated embryos was significantly higher in the demiembryo group than in the intact embryo group ( $\mathrm{p}<0.0001)$ and the developmental rate significantly lower than in intact embryos $(\mathrm{p}<0.01)$.

\section{Freezing/thawing}

The influence of the freezing/thawing on the survival of the embryos was evaluated either by transfer or by reculture as indicated in Tables 3 and 4, respectively.

\section{Transfer}

There was no significant difference in pregnancy rate at 50 days between the fresh and frozen/thawed demiembryos, but the calving rate was significantly lower $(\mathrm{p}<0.01)$ after transfer of frozen/thawed demiembryos as compared with fresh ones. 
Table 2. Distribution of cultured fresh embryos according to number of stages through which, they developed.

\begin{tabular}{lcccc}
\hline \multirow{2}{*}{$\begin{array}{l}\text { Type of } \\
\text { embryos }\end{array}$} & $\begin{array}{c}\text { No. of } \\
\text { embryos }\end{array}$ & $\begin{array}{c}\text { No. dege } \\
\text { nerated }\end{array}$ & \multicolumn{2}{c}{ No. embryos developing through } \\
\hline Intact embryos & 95 & $11(11 \%)^{\mathrm{a}}$ & $39(41 \%)$ & $46(48 \%)^{\mathrm{a}}$ \\
Demiembryos & 243 & $80(33 \%)^{\mathrm{b}}$ & $102(42 \%)$ & $61(25 \%)^{\mathrm{b}}$ \\
\hline
\end{tabular}

a and b: Numbers in the same column with different superscripts are significantly different.

Table 3: Pregnancy results and calving rates after transfer of fresh and cultured/frozen demiembryos.

\begin{tabular}{lccc}
\hline $\begin{array}{l}\text { Type of transferred } \\
\text { demiembryos }\end{array}$ & $\begin{array}{c}\text { No. of } \\
\text { transferred }\end{array}$ & $\begin{array}{l}\text { Pregnant } \\
\text { at 50 days }\end{array}$ & $\begin{array}{l}\text { Number of } \\
\text { calves born }\end{array}$ \\
\hline Demiembryos fresh & 141 & $37(26 \%)$ & $32(23 \%)^{\mathrm{a}}$ \\
Demi cultured/frozen & 48 & $11(23 \%)$ & $2(4 \%)^{\mathrm{b}}$ \\
\hline
\end{tabular}

$a$ and b: Numbers in the same column with different superscripts are significantly different.

\section{Reculture}

The development rate at culture following freezing/thawing was evaluated by the capability of the embryos to enter a number of developmental stages (through $\mathrm{CM}, \mathrm{YB}, \mathrm{BL}$, $\mathrm{XB}, \mathrm{HB}$, and $\mathrm{HA}$,) and the results are presented in Table 4. The number of degenerated embryos was significantly higher in the demiembryo group as compared with the intact embryo group ( $\mathrm{p}<0.02)$, and the intact embryos showed a higher capability to enter through more developmental stages than the demiembryos did.

\section{Discussion}

The present study clearly showed that culture prior to freezing did not improve the survival of demiembryos.

In a comparative study of transfer of fresh versus frozen/thawed agar embedded bisected embryos Picard et al. (1985) found pregnancy rates of $60 \%$ and $23 \%$, respectively, indicating considerable reduction of viability by freezing. Seike et al. (1991) investigated the effect of agar embedding upon freezing ability and found by morphological evaluation that $26 \%$ of the agar embedded and $40 \%$ of the non embedded demiembryos were transferable. The calving rate of the transferred demiembryos was as low as $25 \%$.

A lower developmental rate of frozen versus fresh demiembryos was also reported by Lehn Jensen (1986). Bielanski \& Hare (1988) obtained reduced survival rate after $24 \mathrm{~h}$ culture following thawing, indicating that demiembryos require additional physical protection against freezing injury. Thus Nieman et al. (1986) found, by freezing demiembryos sealed with an additional zona pellucida, that this procedure improved the developmental capacity of frozen/thawed demiembryos, and that freezing demiembryos was more efficient than splitting frozen/thawed intact embryos. Culture prior to freezing was attemted by Chesne et al. (1987) who cultured 8 day old demiembryos without zona pellucida and con- 
Table 4. Distribution of recultured embryos according to the number of stages through which they developed.

\begin{tabular}{lcccc}
\hline \multirow{2}{*}{$\begin{array}{l}\text { Type of } \\
\text { embryo }\end{array}$} & $\begin{array}{c}\text { No.of } \\
\text { embryos }\end{array}$ & $\begin{array}{c}\text { No.dege- } \\
\text { nerated }\end{array}$ & \multicolumn{2}{c}{ No. of embryos developing through } \\
\hline Intact embryos & 14 & $5(36 \%)^{\mathrm{a}}$ & $0-1$ stages & $2-5$ stages \\
Demiembryos & 32 & $23(72 \%)^{\mathrm{b}}$ & $4(28 \%)$ & $5(36 \%)^{\mathrm{a}}$ \\
\hline
\end{tabular}

a and b: Numbers in the same column with different superscripts are significantly different.

cluded that a short 4-6 $\mathrm{h}$ culture period before freezing was beneficial. However, by culturing demiembryos before freezing and making a morphological evaluation by reculture after thawing, Schrøder (1988) found no beneficial effect of the culture since all demiembryos from this group were degenerated after $24 \mathrm{~h}$ reculture.

The objective of the present study was to render the demiembryos more resistant to the freezing damage by culture on BOEC prior to freezing. This period of growh would possibly allow the embryos to regenerate and increase the cellnumber allthough in prolongation of the initial rapid repair of the cellular embryonic organization described by Albihn et al. (1990).

Two thirds of the fresh demiembryos displayed further development during the $24 \mathrm{~h}$ culture and approximately 1 quarter developed through more than 1 embryonic stage (Table 2). Approximately $90 \%$ of the intact embryos developed and almost $50 \%$ through more than 1 embryonic stage. This compromised developmental capacity of the demiembryos is not surprising, as they were handled more extensively, and they were injured ( $\mathrm{Al}$ bihn et al. 1990) as the splitting process itself inflicts a loss of 10-15 blastomeres (Chesne et al. 1987).

That the handling time per se probably compromised the viability of embryos is seen from the fact, that intact embryos from donors from which embryos also were bisected, gave a lower pregnancy rate $(32 \%)$ than embryos from simultaneous flushings where the transfers were not delayed by a micromanipulation process $(52 \%)$.

Evaluation of the viability after culture/freezing/thawing was made by 1 of 2 measurements: either transfer or reculture. The reason for using both methods was that the reculture gives an opportunity to follow the fate of an embryo, but gives unrealisticly high survival rates as compared to the result after transfer (Heyman \& Chesne 1988, Schmidt et al. 1991).

After transfer of the frozen demiembryos there was a surprising significant reduction in number of fulltermed pregnancies (Table 3). Thus the number of 50-days pregnancies was high compared with the number of calves. This dramatic embryonic loss in the cultured/frozen group as compared to the fresh demiembryos is probably caused by the extra loss in viable cells inflicted by the freezing and thus compromizing the formation of the inner cell mass. A reduction over a certain magnitude is incompatible with normal embryogenic survival, but may allow throphoblast formation and implantation (Willadsen 1982, McVoy et al. 1990).

The poor survival rates after transfer corresponds well to the reculture result shown in 
Table 4 . Only $28 \%$ of the demiembryos survived the freezing and only $1 / 3$ of these developed more than 1 stage in the reculture period. Of the intact embryos, $64 \%$ survived the freezing after culture.

A reduced survival rate after freezing of half embryos compared with intact embryos was also found in a study by Lehn-Jensen \& Willadsen (1983). They concluded, that the spare capacity present in embryos containing normal numbers of viable cells is important for the survival after freezing and thawing. Nieman et al. (1986) suggested that in embryos with half the number of blastomeres a few further degenerated blastomeres after freezing can be critical for their subsequent development. McEvoy \& Sreenan (1990) explained the lower survival after transfer of demiembryos by the fact, that the reduced cell mass has an impared capability to give the embryonic signal, which is critical for the maintenance of the luteal function.

These hypothesis are to be sustained, but based on this study it be can concluded, that demiembryos could be cultured for some time in BOEC and still kept viable, but that this culture period had no beneficial effect on their freezability.

\section{Acknowledgement}

A part of this work was supported by the Animal Biotechnology Research Center, The Royal Veterinary and Agricultural University, Copenhagen.

\section{References}

Albihn A, Rodriguez-Martinez H, Gustafson H: Morphology of day 7 bovine demi-embryos during in vitro reorganization. Acta anat. 1990,138, 42-49.

Albihn A, Gustafsson H, Rodriguez-Martinez H: Morphology of day-7 bovine demi-embryos and their post-transfer Viability. Reprod.dom. Anim. 1991, 26, 85-87.

Bielanski A, Hare W C D: Survival in vitro of bovine demiembryos after freezing by slow cooling rates or vitrification. Theriogenology 1988, 29, 223.

Chesne P, Heyman Y, Chupin D, Procureur R, Menezo Y: Freezing of cattle demiembryos: Influence of a period of culture betwween splitting and freezing on survival. Theriogenology, 1987, 27, 218.

Heyman Y, Chesne P: Development of cattle embryos after splitting or throphoblast biopsy and freezing. 11th Int. Congr. Anim. Repr. and A.I.,Dublin, 1988, 2, 167.

Holm P, Greve T, Bak A, Schmidt M: Bisection of bovine morulae and blastocysts from superovulated danish dairy cows. Acta vet. scand. 1991, 32, 47-53.

Lehn-Jensen H, Willadsen S: Deep-freezing of cow 'half' and 'quarter' embryos. Theriogenology, 1983, 19, 49-54.

Lehn-Jensen H: Cryopreservation of bovine embryos The Royal Veterinary and Agricultural University Copenhagen. Thesis. 1986. 183 pp.

McEvoy T G, Sreenan J M: Effect of embryo quality and stage of development on the survival of zona pellucida-free cattle demi-embryos. Theriogenology, 1990, 33, 1245-1253.

Nieman H, Brem G, Sacher B, Smidt D, Krausslich $H$ : An approach to sussecfull freezing of demiembryos derived from day-7 bovine embryos. Theriogenology, 1986, 25, 519-524.

Picard L, King A, Betteridge K.J.: Production of sexed calves from frozen/thawed embryos. Vet. Rec. 1985, 117, 603-608.

Picard L, Schneider U, Betteridge $K J$, King $W A$ : Effect of the zona pellucida, agar embedding and culture on the survival of micromanipulated bovine embryos after freezing and thawing. J. In Vitro Fertilization and Embryo Transfer, 1988, 5, 268-274.

Schmidt M, Avery B, Purwantara B, Roschlau K, Greve T: In vitro culture of bovine demi-embryos on bovine oviduct ephithelial feeder cells. Reprod.dom.Anim. 1990, 25, 167-172.

Schmidt M, Avery B, Smith S: Culture of frozen/thawed bovine demi-embryos with bovine oviduct epithelial cells. Reprod. dom. Anim.1991, 26, 88-91.

Schröder A, Miller J R, Thomsen P D, Roschlau K, Avery B, Poulsen P H, Schmidt M, Schwerin M: Sex determination of bovine embryos using the polymerase chain reaction. Anim. Biotech. 1990, 1, 121-133.

Schrøder U.: Cryopreservation of intact and splitted 
bovine embryos with glycerin and Gelee Royal. Inaug.-Diss. Hannover, 1988.

Schwidersky H, Seifert F, Genz S: Bovine embryo splitting-International trend and own results. Arch.Tierz, Berlin, 1990, 33, 139-48.

Seike N, Sakai M, Kanagawa H: Development of frozen-thawed demiembryos and production of identical twin calves of different age. J.vet.med.Sci.1991, 53, 37-42.

Shelton, $J N$ : Factors affecting viability of fresh and frozen/thawed sheep demi-embryos. Theriogenology, 1992, 37, 713-721.

Smith S D, Schmidt M, Greve T: Transfer of bisected cattle embryos within the same zona pellucida. Reprod.Dom.Anim.1991, 26, 91-93.

Willadsen S: Micromanipulation of embryos of the large domestic species. Diss. The Royal Veterinay and Agricultural University, Copenhagen (1982)

SAS Institute Inc: SAS/STAT Guide for Personal Computers, Version 6.03. Cary, NC, USA, 1988.

\author{
Sammendrag \\ »Frysning af halve kvagembryoner efter forud- \\ gående dyrkning «. \\ Halve embryoner, demiembryoner, som fryses,
}

optøs og overføres, giver en meget lav drægtighedsprocent. Formålet med dette forsøg var at undersøge, om det var muligt at forbedre frysbarheden af demiembryoner ved at dyrke dem i $24 \mathrm{t}$ med bovine ovidukt epithel celler (BOEC). Dette dyrkningssystem skulle give demiembryonerne mulighed for at regenerere og i løbet af dyrkningsperioden forøge celleantallet. På denne måde skulle de gøres mere egnede til at overleve fryseskaderne. Deres viabilitet efter frysning blev vurderet dels ved drægtigheds procent efter overførsel og dels ved udviklingsevne under $24 \mathrm{t}$ genoptaget dyrkning. Ved dyrkning af 243 demiembryoner viste det sig, at de både før og efter frysning havde en dårligere udviklingkapacitet end intakte embryoner.

Ved overførsel af 48 dyrkede og frosne demiembryoner opnåedes en drægtighedsfrekvens på $23 \%$, mens kælvingsfrekvensen kun var på $4 \%$. Ved overførsel af 142 friske demiembryoner var de tilsvarende tal henholdsvis $26 \%$ og $23 \%$. Det kunne tolkes således, at demiembryonerne efter dyrkning og frysning har celler nok til at danne fosterblære, men for få til at danne selve fosteret.

Forsøget viste således, at dyrkning med BOEC ikke forbedrede frysbarheden af halve bovine embryoner.

(Recieved April 7,1992; accepted May 6, 1992).

Reprints may be requested from: M.Schmidt, Department of Clinical Studies, Reproduction, Royal Veterinary and Agricultural University, 13 Bülowsvej, DK-1870 Frederiksberg C, Denmark. 